\title{
TODOS OS ESTADOS SÃO IGUAIS, MAS ALGUNS SÃO MAIS IGUAIS QUE OS OUTROS
}

\section{Pedro Neiva}

https://orcid.org/0000-0002-4888-7515

\section{Taeko Hiroi}

(iD) https://orcid.org/0000-0003-0751-9342

(1) Universidade de Brasília (UnB), Brasília - DF, Brasil. Email: prneiva@gmail.com

(2) Department of Political Science of the University of Texas at El Paso (UT), El Paso - Texas, USA. E-mail: thiroi@utep.edu

DOI: $10.1590 / 3510301 / 2020$

\section{Introdução}

Nesse artigo, procuramos avaliar a distribuição de poder entre os estados brasileiros, tanto no Poder Executivo quanto no Legislativo, ao longo da história da República. Nosso objetivo é verificar se existe uma lógica ou justificativa regional para a distribuição dos principais cargos públicos do país. De forma mais direta, pretendemos averiguar se a sub-representação legislativa dos estados/regióes maiores (e coincidentemente mais desenvolvidos) e a sobre-representação dos estados/regióes menores (e coincidentemente menos desenvolvidos) se reproduzem no Poder Executivo. Em outras palavras, nosso intuito é avaliar se a desproporcionalidade de representação existente no Legislativo se estende para o Executivo.

Artigo recebido em: 09/06/2018

Aprovado em: 15/11/2019
Consideramos a desproporcionalidade em um contexto mais amplo, abrangendo não apenas o Poder Legislativo, mas também o Executivo. Afinal, a dimensão regional é também um componente importante na escolha dos ministros pelo presidente (Abranches, 1988). Se o Executivo é o "centro de gravidade" (Amorim Neto, 2007), o "pivô" do sistema político (Palermo, 2000), e se seus cargos exercem atração especial sobre os políticos brasileiros (Samuels, 2002, 2003), por que não levá-lo em consideração também no que diz respeito à desproporcionalidade de representação?

A literatura antiga sobre a desproporcionalidade de representação no Brasil defendia a ideia de que ela era, antes de tudo, um pacto conservador entre elites para aumentar a representação de regióes pobres, com maior proporção de eleitores analfabetos e com baixo nível de consciência política. Dessa forma, evitaria-se o avanço da classe trabalhadora, que tinha seus representantes 
concentrados nos estados e regióes ricos (Britto, 1965; Kinzo, 1990; Soares, 1973; Tavares, 1995). Tal visão casa com a sugestão de Snyder e Samuels (2004, p. 134) de que, na América Latina, a desproporcionalidade "serviu e continua a servir como uma arma política das elites rurais e conservadoras, que persiste em muitos legislativos, onde os segmentos urbanos populares mantêm-se altamente sub-representados". Consequentemente, haveria menos governabilidade e menor possibilidade de aprovação de reformas progressistas; a desproprorcionalidade prejudicaria a formação de partidos novos, modernos e reformistas (Kinzo, 1990; Soares, 1973; Tavares, 1995).

Essa não é, porém, uma visão unânime. Há autores que defendem algum grau de desporporcionalidade, inclusive como mecanismo para evitar a tirania da maioria (Santos, 1997; Soares e Lourenço, 2004). No contexto brasileiro, não deixa de ser também preconceituosa, já que assume, sem apresentar evidências consistentes, que as forças políticas do Sul e do Sudeste são "modernas" e "avançadas" e as do Norte, do Nordeste e do Centro-Oeste, "atrasadas" ou "arcaicas". Acrescente-se que se trata também de uma visão ultrapassada, dado o avanço do Partido dos Trabalhadores nas regióes mais pobres (e, muitas vezes, sobre-representadas) do país.

Nossa questão aqui é saber se tal desporporção esteve presente também no Poder Executivo. A literatura sobre governos de coalizão mostrou que, a exemplo do que acontece nos sistemas parlamentaristas, os presidentes costumam também formar suas coalizóes de governo com base nos partidos (Amorim Neto, 2000, 2006; Carey \& Reinhardt, 2004; Martínez-Gallardo, 2012). Como a desproporcionalidade de representação acaba tendo um impacto sobre o tamanho dos partidos, favorecendo aqueles que têm uma presença maior em regióes sobre-representadas (Neiva, 2011; Reynoso, 2001), é razoável supor que tais regióes terão também uma participação na formaçáo do Gabinete. Esse impacto tende a ser ainda maior nos sistemas presidencialistas bicamerais, nos quais os legislativos costumam ser mais desproporcionais (Snyder \& Samuels, 2004), e as câmaras altas contam com mais poderes (Lijphart, 1999; Llanos \& Nolte, 2003; Neiva, 2006). Isso por que os presidentes terão que levar esses fatores em consideração ao formar a sua coalizão (Albala, 2017; Hiroi \& Renno, 2014). É o caso do Brasil.

O estudo abrange todo o período republicano, de 1889 a 2017. Abrange também todos os estados e regiôes, diferentemente do que fizeram a grande maioria dos autores que estudaram o assunto e os analisaram individualmente. Entre outras, nossa pesquisa têm como guia as seguintes perguntas: existe diferença expressiva entre os estados e regiôes, no que diz respeito à ocupação de cargos no Executivo? A desproporcionalidade que se observa no Legislativo repete-se no Executivo? Até que ponto a sobre-representaçáo dos estados do Norte, do Centro-Oeste e do Nordeste favoreceu a obtenção de cargos no Executivo? São Paulo desempenhou, de fato, um papel inferior à sua dimensão e peso econômico, conforme afirma Schwartzman (1982)? Quem, efetivamente, ganha e perde com essa configuração?

O artigo está estruturado em quatro seções, além dessa introdução. Na seção que se segue, retomamos a discussão da literatura sobre os fatores que reforçam e amenizam o constrangimento ao poder central, com destaque para a desproporcionalidade de representação. Em seguida, na seção II, apresentamos nossos dados e fontes, e fazemos algumas consideraçóes sobre o período analisado. $\mathrm{Na}$ seção III, interpretamos e analisamos os dados. Por fim, na seção IV, apresentamos nossas conclusóes e sugestões de estudos futuros.

\section{Os fatores demos constraining e demos enabling do sistema político brasileiro}

Parte importante da literatura em ciência política tem pesquisado os sistemas federativos a partir das dificuldades que eles geram para a tomada de decisão do governo central. A ideia é que eles aumentam o número de atores de veto, capazes de constranger as iniciativas dos governos em torno do processo de reformas (Lijphart, 1999; Samuels \& Mainwaring, 2004; Tsebelis, 1995). Stepan (2004) os classifica por meio de um continuum, de acordo com o grau de constrangimento (ou de obstrução) que impóem ao poder central. Variam, portanto, 
de um grau mínino (demos enabling) a um grau máximo de constrangimento (demos constraining).

A desproporcionalidade de representação tem sido considerada como um dos fatores desse constrangimento. Ela influencia a performance geral dos sistemas políticos, ao interferir na forma de relacionamento entre o Executivo e o Legislativo. Trata-se de elemento importante na formação da coalizão de governo, impactando a tomada de decisão e a elaboração de políticas públicas (Samuels \& Snyder, 2001). Segundo Snyder e Samuels (2004), ela faz com que o Legislativo seja dominado por interesses mais rurais, e o Executivo, por interesses urbanos. Na visão dos dois autores, isso contribui para o estranhamento e o impasse entre os dois poderes. Para superá-los, o presidente precisa comprar o suporte legislativo das áreas rurais, supostamente mais barato que o apoio dos representantes das áreas urbanas (Gibson et al., 2004).

O Brasil tem sido colocado como caso emblemático no que diz respeito à dificuldade de adoção de políticas nacionais. Em grande parte, isso acontece em função da combinação de presidencialismo, sistema eleitoral de lista aberta e sistema partidário altamente fragmentado, considerada caótica para a capacidade governativa (Ames, 2003; Samuels, 2003). Além disso, o presidente brasileiro precisa levar em conta os aspectos regionais, tais como a influência dos governadores sobre as bancadas dos seus estados no Congresso (Abranches, 1988; Abrucio, 1998; Ames, 2003; Gibson et al., 2004; Samuels \& Mainwaring, 2004; Schwartzman, 1982; Souza, 1998) e também para a formaçấo da sua equipe de governo (Meneguello, 1998; Amorim Neto, 2000).

De acordo com Alfred Stepan $(1999,2004)$, o Brasil é um caso extremo de federalismo demos constraing. Segundo o autor, os problemas principais são o fato de o país, além de não contar com partidos nacionais, possuir uma câmara alta com amplos poderes e desproporcionalidade de representação altíssima em ambas as casas. Para o autor, a desproporcionalidade aumenta os riscos de paralisia decisória, ao possibilitar que minorias regionais vetem propostas voltadas aos interesses da maioria. Na mesma linha, Reynoso (2001) vê a desproporcionalidade como um problema para a governabilidade, ao promover a formação de partidos regionais, diminuir a disciplina e aumentar a migração partidária.

A percepçáo da desproporcionalidade como um problema para o governo não é, contudo, unânime. Alguns autores a consideram um facilitador de suas ações e decisōes; ela estaria, assim, mais para um fator demos enabling do que demos constraining. Segundo Tommasi (2002), na Argentina, a principal fonte de suporte do governo peronista não veio das cidades industriais, mas dos votos rurais das províncias menos desenvolvidas e sobre-representadas. Samuels e Mainwaring (2004) consideraram que a desproprocionalidade facilitou as reformas constitucionais realizadas no Brasil, tendo em vista que regiōes menos desenvolvidas deram maior suporte às propostas dos presidentes. $\mathrm{Na}$ mesma linha, Neiva e Soares (2011) verificaram que a desproporcionalidade ajudou a implementar a agenda do Executivo: os autores descobiram que, quanto mais sobre-representado era o estado de origem de um senador, maior era sua tendência de votar de acordo com a vontade do governo.

Tomaremos emprestado os conceitos de Stepan (2004), que se limitam à questáo da sub ou super-representação nas casas legislativas, para mostrar que, no Brasil, a distribuição de cargos mais importantes privilegia regiōes/estados mais populosos, compensando-se a sobre-representaçáo de unidades menos populosas no Legislativo. Esse estudo converge com uma literatura mais ampla, que analisa as relaçóes entre o Executivo e o Legislativo no país e identifica uma série de instrumentos que permitem ao presidente governar. Eles incluem os poderes legislativos do presidente e a forma centralizada de organizaçáo do Congresso Nacional (Figueiredo e Limongi, 1999); o uso estratégico da execuçáo de emendas orçamentárias (Pereira e Mueller, 2002); e o compartilhamento do poder por meio de ministérios (Amorim Neto, 2000). Nesse artigo, defendemos a ideia de que a preponderância dos estados maiores em alguns cargos nacionais também provoca esse efeito. Ela seria um elemento a mais na "caixa de ferramentas" que ajuda o presidente a governar.

A ideia não é verdadeiramente nova. Alguns autores já haviam sinalizado que a desproporcionalidade de representação não foi de todo má para os estados ricos. Segundo Gláucio Soares (1973, 
pp. 12-13), a emenda constitucional que limitou o número de deputados de Sáo Paulo, em 1969, não provocou qualquer reação por parte das forças políticas do estado, porque percebeu-se que "era melhor abandonar o problema da representação no Legislativo e focalizar na representação nos órgãos e postos importantes da administração pública, como os ministérios da Fazenda e do Planejamento, o Banco do Brasil etc.”. Na opinião de Campello de Souza (2006), a barganha federativa passava pela sobre-representação dos estados menos desenvolvidos no Congresso e pela predominância dos estados mais industrializados nas arenas decisórias relacionadas às grandes políticas econômicas. Na visão de Barry Ames (1986, p. 198), São Paulo permitiu que outros estados se apropriassem de pequenos projetos fisiológicos, enquanto permanecia controlando integralmente a política macroeconômica, os investimentos e as políticas fiscal e cambial. De acordo com o autor, os paulistas não estiveram nem sobre nem sub-representados nas pastas ministeriais, mas dominaram os órgãos cruciais: os ministérios da Fazenda e Obras Públicas e o Banco do Brasil. Não sabemos se esse foi um pacto explícito e consciente entre os estados, pois não temos evidências que confirmem essa possibilidade. Mas ele parece ter viabilizado a divisão de poderes entre os estados no Brasil republicano.

No entanto, os autores mencionados fizeram suas sugestóes de forma impressionista, intuitiva, sem demonstrar o que ocorria efetivamente. Tentaremos fazer algo diferente aqui, avaliando a ocupação dos cargos principais por um longo período de tempo. Na seção que se segue, apresentamos informaçóes sobre nossos dados e discutimos alguns aspectos metodológicos.

\section{Informaçóes sobre dados e aspectos mercadológicos}

São raros os estudos que consideram o peso político dos estados na federação. Aqueles que foram realizados concentraram-se em momentos e estados específicos, a saber: Rio de Janeiro (Amorim Neto e Santos, 2013); Pernambuco (Levine, 1980); São Paulo (Schwartzman, 1975, Love, 1980); Minas
Gerais (Wirth, 1982); e Rio Grande do Sul (Love, 1985). Um estudo desse tipo, que aborda todos os estados e um período tão longo de tempo, não nos possibilita aprofundar a avaliação de aspectos específicos, ou controlar fatores explicativos importantes. Mas nos permite enxergar o grande quadro que as análises individuais nem sempre deixam ver.

Trabalhamos aqui com informaçóes sobre alguns dos cargos públicos mais importantes do país em todo o período republicano, de 1889 a 2017. Esse conjunto abarca 10.780 deputados, 2.123 senadores e 1.027 autoridades governamentais: 38 presidentes da República, 27 vice-presidentes, 875 ministros de Estado, 26 presidentes do Banco Central e 61 presidentes do Banco do Brasil. ${ }^{1}$ A unidade de análise é o cargo, e não a pessoa. O mesmo cargo entrou na contagem todas as vezes em que houve mudança de ocupante, independentemente do tempo de permanência. Descartamos apenas as ocupaçóes exercidas interinamente ou por menos de um mês.

As informações dizem respeito, basicamente, ao principal vínculo estadual dessas autoridades. No caso de deputados e senadores, estamos considerando as unidades federativas pelas quais se elegeram. Nos casos de presidentes e vice-presidentes da República, consideramos os estados onde conduziram suas carreiras políticas. O ex-presidente Jânio Quadros, por exemplo, nasceu em Mato Grosso, mas fez carreira política no estado de São Paulo, onde foi vereador, deputado estadual e governador, antes de se eleger presidente.

Ainda com relação aos presidentes da República, incluímos no banco de dados aqueles que foram eleitos, mas não tomaram posse. É o caso, por exemplo, de Tancredo Neves, que faleceu antes de ser empossado, e de Júlio Prestes, impedido de tomar posse pela Revolução de 1930. Nossa decisão considera que o importante é estimar a força política dos atores, e, mais especificamente, de seus estados/regióes de atuação, e não sua atuação efetiva no exercício da presidência. Pelo mesmo motivo, estamos considerando como presidentes, os vice-presidentes que tomaram posse definitiva do cargo.

No caso dos ministros, estamos igualmente considerando os estados em que fizeram suas carreiras políticas. Não obstante, é importante dizer que nem sempre foi possível obter tal informação, 
já que alguns foram escolhidos por critérios predominantemente técnicos, a exemplo de alguns funcionários de carreira; é o que muitas vezes aconteceu no Ministério das Relaçóes Exteriores, com uma maioria de titulares oriunda da carreira diplomática. Levantamos informaçóes sobre dezenove ministérios, criados há pelo menos trinta anos, desde o processo de retomada da democracia, em 1985. Os ministérios militares foram extintos em 1999, quando surgiu o Ministério da Defesa; por isso, passamos a considerar os comandantes das três armas como se fossem seus respectivos ministros.

No caso do Banco do Brasil, apenas 37 (61\%) dos presidentes que passaram pela instituição foram levados em conta. Os 39\% restantes eram funcionários de carreira, o que dificultou a identificação das motivaçóes políticas de sua escolha. Os titulares do Banco Central eram essencialmente tecnocratas, como seria de se esperar de uma instituição que cuida da estabilidade da moeda e precisa, para isto, de alguma autonomia. ${ }^{2}$ Não estamos dizendo que não não houve interferência política na indicação; essa, porém, parece vir mais do mercado do que dos atores políticos, partidários e/ou regionais. Assim, tomamos como referência o local de nascimento desses atores.

Os dados sobre os deputados foram fornecidos por Jairo Nicolau e complementados em consulta à página da Câmara dos Deputados na internet. As informaçóes relativas aos senadores foram retiradas do site do Senado; as demais autoridades foram pesquisadas em consulta ao Dicionário histórico-biográfico brasileiro, publicado pelo CPDOC (Abreu et al, 2001). Dados sobre os presidentes do Banco Central e do Banco do Brasil foram complementados por informaçóes disponibilizadas nas páginas das duas instituiçôes na internet.

Os cargos de ministro e de presidentes do Banco Central e do Banco do Brasil foram classificados como "políticos" quando os escolhidos exerceram alguma função desse tipo nos estados, em cargos eletivos, como secretários estaduais ou presidentes de sindicatos ou associaçóes, participando na criação de partidos etc. Para classificar um perfil como "técnico/tenocrático" ou "não político", levamos em consideração diversos aspectos, além da ausência do critério anterior. Eles incluem: 1) o fato do escolhi- do ser militar: apesar de frequentemente implicar o exercício de comandos em diversas regiōes do país, não podemos assumir que seja por interferência das forças políticas regionais; 2) uma formação acadêmica aprofundada em nível de mestrado e/ou doutorado, muitas vezes no exterior, como é o caso de grande parte dos presidentes do Banco Central; 3) a permanência, em carreira, no órgão do qual foi titular, como é o caso de vários presidentes do Banco do Brasil e de ministros das relações exteriores.

A análise será feita principalmente tomando como referência as cinco regiôes do país. Isso não é o ideal, já que os estados de uma mesma região são heterogêneos; ainda assim, julgamos que seja a melhor opção a adotar aqui, por vários motivos. Em primeiro lugar porque, embora tenha havido variação na desproporcionalidade durante o período republicano, ela não foi absurdamente alta, conforme podemos observar no apêndice 1. Em segundo lugar porque, apesar das diferenças, existe alguma homogeneidade entre estados de uma mesma região: em geral, houve mais sobre-representação no Norte, no Centro-Oeste e no Nordeste, que também têm uma maioria de estados pobres e com índices de desenvolvimento humano baixos. O contrário tende a acontecer no Sul e no Sudeste. Além disso, foi essa a estratégia usada na literatura que tratou do assunto. A maioria dos autores fez a análise a partir das regióes. A análise de cada um dos 27 estados, envolvendo um período tão longo e onze cargos diferentes, dificultaria substancialmente a leitura do texto, sobretudo considerando que fizemos também um recorte em dois períodos: democrático e não democrático (ver tabela 5).

Náo obstante, usamos exemplos relativos aos principais estados, em particular, procurando salientar as características que são comuns à maior parte da regiáo. Merecem destaque os estados de São Paulo, Minas Gerais, Rio Grande do Sul e Rio de Janeiro. O primeiro porque se tornou o estado mais populoso do país, o mais importante do ponto de vista econômico e o de maior sub-representação no Legislativo. O segundo porque, a despeito do seu declínio econômico no período, continuou sendo o fiel da balança e tendo participação decisiva nos acontecimentos políticos nacionais (Wirth, 1982). O Rio Grande do Sul nunca foi um polo econômico 
dominante, e está a milhares de quilômetros da capital do país, mas apresenta uma forte tradição militar e, desde fins do século XIX, desempenhou um papel bastante ativo na política nacional (Schwartzman, 1982), tendo sido palco de três guerras e do maior movimento seccionista da história do país (Farrapos). No caso do Rio de Janeiro, o destaque é dado porque o estado tem, tradicionalmente, um dos maiores PIB e população do país (Amorim Neto e Santos, 2013). É importante observar, também, o fato da cidade do Rio de Janeiro ter sido capital do país até 1960, o que garantia a presença, ali, de elites políticas e intelectuais. Vale acrescentar que a desproporcionalidade, nas duas casas legislativas, é realçada, principalmente, pela sub-representação de São Paulo e pela sobre-representação dos estados criados, nas últimas décadas, no Norte do país.

Uma pesquisa que considera um número elevado de casos e um período muito longo de tempo nos permite alcançar uma visão global e sugestiva da lógica de distribuição do poder. Por outro lado, nos impede de controlar aspectos importantes, que poderiam trazer maior segurança às explicações. Ficaria muito difícil, por exemplo, avaliar as conexóes partidárias de cada uma das autoridades envolvidas. Assim, não pretendemos proporcionar respostas específicas e taxativas. Outros estudos poderão ser empreendidos nesse sentido. $\mathrm{O}$ nosso acrescenta elementos pouco explorados à análise do arranjo federativo brasileiro, apresentando perspectiva e dados novos, no intuito de contribuir para uma melhor compreensão do tema.

\section{Consideraçôes sobre o periodo analisado}

Muita coisa mudou ao longo do período analisado. A desproporcionalidade, tanto no Legislativo quanto nos outros órgãos, não foi sempre a mesma. Mudou também a importância dos estados. Houve uma troca de posição entre Minas Gerais e São Paulo, em termos econômicos e populacionais; o Rio de Janeiro perdeu algum prestígio com a transferência da capital para Brasília; o Rio Grande do Sul teve maior evidência e peso político durante os períodos autoritários; a desigualdade econômica regional foi levemente reduzida em anos recentes, durante os governos do Partido dos Trabalhadores. No entanto, a despeito do grande intervalo de tempo, náo fazemos aqui uma análise histórica minuciosa. Apresentamos dados gerais em relação a cada um dos períodos, mas não nos cabe entender e explicar pormenorizadamente todas as transformaçóes que ocorreram.

Acreditamos que essas mudanças não prejudicam nossa análise, até mesmo porque a proporção de distribuição regional dos cargos não se alterou substancialmente, a não ser na região Sul. A região Sudeste variou de $50 \%$ a $57 \%$ dos cargos. A Nordeste, de $20 \%$ a $29 \%$. As regióes Norte e Centro-Oeste estiveram sempre sub-representadas no Poder Executivo, a despeito da sua sobre-representação no Legislativo. Além disso, os quatro estados principais do país permaneceram os mesmos. O Sul e o $\mathrm{Su}$ deste continuaram sendo as regióes mais desenvolvidas, "mantendo o Norte e o Nordeste como uma espécie de colônia interna do Sul dinâmico" (Love, 1980). Para dar uma ideia dessa relativa estabilidade, apresentamos no apêndice 1 a variaçáo regional no tamanho da população e nos cargos ocupados, no Legislativo e no Executivo, por cada uma das regiôes nos cinco períodos da história do Brasil.

Manteve-se inalterada, também, a base da configuração institucional do país: presidencialismo, federalismo e bicameralismo simétrico. Além disso, a elite política dos principais estados permaneceu extremamente homogênea, pelo menos no primeiro meio século do regime republicano. De acordo com Love (1980), os políticos eram, em geral, recrutados nas mesmas camadas sociais, cuja identidade era dada por experiências e valores partilhados e padróes de carreira muito semelhantes. Sete dos doze presidentes da República Velha, por exemplo, receberam seu diploma na Escola de Direito de Sáo Paulo.

Como forma de lidar com o impacto das mudanças na pesquisa, fizemos duas análises separadas: a primeira envolve toda a história republicana; a outra abrange apenas os períodos democráticos, com eleiçóes de massa (de 1946 a 1964 e de 1985 a 2017). Dessa forma, evitamos as possíveis distorçôes dos períodos autoritários, já que governos desse tipo têm muito menos necessidade de apoio político. Deixamos de apresentar tais dados nas tabelas referentes às regióes, no intuito de poupar o leitor de um excesso de informaçôes. Sempre que conveniente, relatamos os resultados mais importantes no texto. 


\section{Interpretaçáo dos resultados}

$\mathrm{Na}$ tabela 1, iniciamos nossa análise pela comparação entre os pesos de cada região na composição das duas casas legislativas. Os dados cobrem todo o período republicano e estão expressos em termos percentuais.

A tabela mostra que o Sudeste foi sub-representado nas duas casas legislativas, especialmente no Senado. Apesar de ter abrigado $44 \%$ da população total do país, contou com apenas $22 \%$ dos senadores, metade do que teria em uma situação de proporcionalidade. A outra região rica do país, o Sul, ficou equilibrada na Câmara e levemente sub-representada no Senado. Já as regiōes pobres (Norte, Nordeste e Centro-Oeste) estiveram sobre-representadas nas duas casas. No Senado, a situação é mais perceptível. As três regióes juntas ocuparam 65\% das cadeiras na Casa, embora tenham respondido por apenas $41 \%$ da população no período considerado.

Avaliamos também as consequências da desproporcionalidade sobre a ocupação da presidência das duas casas. São dois cargos fundamentais no sistema político brasileiro - possivelmente, os mais importantes, depois do cargo de presidente da República. São os substitutos do presidente no caso de vacância da vice-presidência; integram os Conselhos da República e de Defesa Nacional, órgáo de consulta obrigatória nos casos de interesse nacional relevante; podem propor a convocação extraordinária do Congresso Nacional; possuem poderes institucionais decisivos para a conduçâo do processo legislativo, influenciando substancialmente no preenchimento de cargos e na definiçáo da agenda de votaçóes. São eles que autorizam a abertura de comissão parlamentar de inquérito, definem o que vai ser votado em plenário e controlam o tempo de discurso dos congressistas. No caso do presidente da Câmara, é ele quem decide sobre a abertura de processo de impedimento contra o(a) presidente da República. A perda do mandato de Dilma Rousseff, por exemplo, poderia ter sido evitada caso ela contasse com um aliado na presidência da Casa. A tabela 2 mostra a ocupação da presidência das duas casas pelas regiốes durante todo o período republicano.

Tabela 1

Proporçáo de Cargos Ocupados no Legislativo pelas Regióes (\%) - 1889 a 2017

\begin{tabular}{lllllll}
\hline & Sudeste & Sul & Nordeste & Norte & Centro-Oeste & N \\
\hline Populaçáo & 43,8 & 14,9 & 30,3 & 6,0 & 4,9 & - \\
\hline Deputados & 38,3 & 14,9 & 32,8 & 8,6 & 5,4 & 10.780 \\
\hline Senadores & 21,6 & 13,2 & 39,6 & 15,3 & 10,3 & 2.123 \\
\hline
\end{tabular}

Fontes: Abreu et al. (2001); sítios do Senado e da Câmara dos Deputados na internet; IBGE; base de dados de Jairo Nicolau (1997); wikipedia.

Tabela 2

Ocupação da Presidência da Câmara e do Senado pelas Regióes (\%) - 1889 a 2017

\begin{tabular}{lllllll}
\hline & Sudeste & Sul & Nordeste & Norte & Centro-Oeste & N \\
\hline Populaçáo & 43,8 & 14,9 & 30,3 & 6,0 & 4,9 & - \\
\hline Senado & 30,0 & 4,0 & 46,0 & 14,0 & 6,0 & 51 \\
\hline Câmara dos Deputados & 63,8 & 10,3 & 25,9 & 0,0 & 0,0 & 55 \\
\hline
\end{tabular}

Fontes: Abreu et al. (2001); sítios do Senado e da Câmara dos Deputados na internet; IBGE; base de dados de Jairo Nicolau (1997); wikipedia. 
Os dados mostram que a sub-representação das regióes ricas - Sul e Sudeste - no Senado traz consequências para a conquista da presidência da Casa. As duas juntas responderam por $59 \%$ da população do país durante a República, mas fizeram apenas 34\% dos seus presidentes, número próximo aos $34 \%$ de representação no período. Se considerarmos apenas os cinquenta anos de governo democrático (1946-1964 e 1985-2017), os números tornam-se ainda mais gritantes: Sul e Sudeste respondem por apenas 20\% dos presidentes do Senado, e as regióes pobres, pelos $80 \%$ restantes. $\mathrm{Na}$ Nova República (1985-2018), nenhum político do Sul ou do Sudeste ocupou o cargo.

Curiosamente, a situação inverte-se na Câmara dos Deputados, que supostamente representa a população. O Sudeste sozinho conquistou $64 \%$ das presidências da Casa no período republicano, número bem superior à sua participação na população do país $(44 \%)$ e à proporção de deputados (38\%). Se isolarmos apenas os dois períodos democráticos, esse número sobe para 79\%. Na Nova República (1985 a 2018), dos dezenove presidentes da Câmara, catorze $(74 \%)$ eram oriundos das regióes mais desenvolvidas, sendo sete (37\%) deles do poderoso estado de São Paulo. ${ }^{3}$ Esses dados nos levam a questionar até que ponto a desproporcionalidade na câmara baixa é, de fato, um problema no Brasil. Apesar da região mais rica ser sub-representada na Casa, aparentemente ela não tem sido alijada do poder, como parece ter acontecido no Senado. Essa é mais uma evidência de que os estados e regióes ricos tendem a expressar o poder da maioria, reduzindo o potencial de constrangimento do governo central.

Fica evidente, portanto, a preponderância das regiōes pobres no Senado, seja no número de senadores, seja na ocupação da presidência. Essa situação deve provocar consequências políticas. Possivelmente, favorece partidos conservadores, e pode motivar transferência de recursos maiores para tais regiōes; talvez tenha implicaçôes para a estratégia de negociação entre o Executivo e o Legislativo. Alguns estudos foram feitos nesse sentido (Gibson et al., 2003; Arretche e Rodden, 2004; Turgeon e Cavalcante, 2014; Neiva, 2011; Neiva e Soares, 2013). Não é propósito desse artigo repeti-los.

Já o mesmo não acontece na câmara baixa.
Parece haver uma certa compensação entre as duas casas do Legislativo, pelo menos no que diz respeito à ocupação das presidências. É curioso que, em ambas, as posiçóes de liderança (formais ou informais) são distribuídas de forma mais ou menos proporcional ao peso eleitoral de cada região. É o que diz estudo realizado pelo Departamento Intersindical de Assessoria Parlamentar (DIAP), grupo de lobby vinculado aos sindicatos de trabalhadores. Entre os cem membros mais influentes do Congresso, incluindo deputados e senadores, $43 \%$ eram do Sudeste, $30 \%$ do Nordeste, $16 \%$ do Sul, $5 \%$ do Centro-Oeste e $6 \%$ do Norte. Fica a impressão de que a distorção na representação eleitoral, em favor dos estados menores, é contrabalançada pela estrutura de liderança, que beneficia os estados maiores, bem como os estados maiores das regiōes pobres.

Ao analisar a ocupação dos cargos no Poder Executivo, verificamos que 52\% dos seus titulares fizeram carreira política na região Sudeste e 16\% na região Sul. As duas respondiam por $44 \%$ e $15 \%$ da população do país no período, respectivamente. Já as regióes pobres foram sub-representadas: o Nordeste teve 25\% dos titulares dos cargos; o Centro-Oeste, $3 \%$; e o Norte, $4 \%$, enquanto, em população, responderam por $30 \%, 6 \%$ e $5 \%$, respectivamente.

Esses resultados são contra-intuitivos. Em teoria, o peso dessas três regióes, em número de assentos, as colocariam em uma posição privilegiada para demandar maior representação no governo. Mas os dados mostram o contrário: as regiōes mais sobre-representadas no Legislativo são aquelas que ocuparam menor número de cargos nos ministérios. Já os estados maiores (e, coincidentemente, ricos), sub-representados no Legislativo, foram compensados com cargos essenciais no Executivo, muitas vezes até mais relevantes que deputado ou senador. Eles estáo detalhados na tabela 3.

A tabela mostra que a região Sudeste prevaleceu em todos os cargos, com patamares sempre acima de $50 \%$, embora sua população não tenha chegado a 44\%. No mais importante cargo público do país, de presidente da República, as duas regióes ricas (Sul e Sudeste), que responderam por apenas 58\% da população no período, foram responsáveis por quase $90 \%$ dos titulares. Os quatro estados principais (São Paulo, Minas Gerais, Rio de Janeiro e Rio 
Tabela 3

Ocupação de Cargos no Executivo pelas Regióes - 1889 a 2017

\begin{tabular}{lllllll}
\hline & Sudeste & Sul & Nordeste & Norte & Centro-Oeste & N \\
\hline Populaçáo & 43,8 & 14,9 & 30,3 & 6,0 & 4,9 & - \\
\hline Presidente da República & 68,4 & 21,1 & 10,5 & 0,0 & 0,0 & 39 \\
\hline Vice-Presidente da República & 56,0 & 8,0 & 36,0 & 0,0 & 0,0 & 30 \\
\hline Ministros & 50,1 & 17,7 & 24,5 & 3,8 & 3,8 & 1.057 \\
\hline Ministro da Fazenda & 57,7 & 15,4 & 19,2 & 1,9 & 5,8 & 72 \\
\hline Ministro do Planejamento & 87,5 & 6,2 & 6,2 & 0,0 & 0,0 & 29 \\
\hline Ministros Militares & 51,9 & 26,0 & 18,3 & 0,0 & 3,8 & 152 \\
\hline
\end{tabular}

Fontes: Abreu et al. (2001); IBGE; wikipedia.

Grande do Sul) fizeram nada menos que $87 \%$ deles. Do Nordeste, que abrigou $30 \%$ da população, vieram apenas $10,5 \%$ dos presidentes. Os números não mudam muito quando consideramos apenas o período democrático: as duas regióes ricas passam a ser responsáveis por $83,3 \%$ dos presidentes; o Nordeste aumenta sua participação para $16,7 \%$; e as regióes Norte e Centro-Oeste continuam sem nenhum representante. Esses dados mostram que a distribuição dos cargos não é aleatória, assim como não parece ser no caso de todos os outros cargos analisados.

No que diz respeito aos vice-presidentes, o Sudeste teve também uma participação alta, quando consideramos todo o período (56\%). Em parte devido à "política do café com leite" da República Velha, quando Minas Gerais e São Paulo alternavam-se na ocupação da presidência e da vice-presidência. Quando consideramos apenas os cinquenta anos que compreendem os dois períodos democráticos, o Sudeste e o Nordeste ficaram com a mesma participação $(37,5 \%)$ e o Sul com $25 \%$. A exemplo do que ocorre com a presidência da República, o Norte e o Centro-Oeste não emplacaram nenhum representante na vice-presidência. Isso contrasta com os $26 \%$ que tiveram de participação no Senado e os $20 \%$ das vezes em que ocuparam a presidência daquela Casa. Cada vez mais, vai ficando claro o contraste entre a sobre-representação das duas regióes no Senado e sua sub-representação nas outras instâncias de poder.
Com relação aos ministros, cargos de nomeação exclusiva do presidente da República, o Sudeste e o Sul responderam por 68\% deles. Quando olhamos para os mais importantes - aqueles ligados à área econômica -, o número sobe. No caso do Ministério da Fazenda, órgão responsável por planejar, formular e executar as políticas econômicas do país, $73 \%$ vieram das duas regióes. O Nordeste respondeu por $19 \%$ dos ministros da pasta. Se considerarmos apenas o período democrático, o Sul e Sudeste aumentam sua participação para $83 \%$, e o Nordeste tem a sua reduzida para $17 \%$.

No Ministério do Planejamento, órgão responsável pela coordenação das políticas de gestão da administração pública, a ocupação do cargo por políticos oriundos do Sudeste aconteceu em nada menos que $88 \%$ das vezes. Nos períodos democráticos, a ocorrência foi praticamente a mesma $(86 \%)$. Os números para o Nordeste foram $6 \%$ e $7 \%$, respectivamente. Políticos do Norte e do Centro-Oeste não ocuparam o Ministério do Planejamento nenhuma vez.

Dos ministérios referentes às forças armadas, $78 \%$ ficaram nas mãos do Sul e do Sudeste. Vale destacar, aqui, a intensa participação do Rio Grande do Sul $(20,4 \%)$ e do Rio de Janeiro (44,6\%), dois estados com forte tradição militar. É curioso que, dos cinco presidentes que governaram o país durante o regime autoritário (1964 a 1985), três tenham nascido no Rio Grande do Sul e um no Rio de Janeiro. ${ }^{4}$ De certa forma, esse poderio militar 
contrabalança o predomínio de Minas Gerais e de São Paulo em outras posiçôes expressivas.

Avaliamos também dois outros cargos importantes na área econômica: as presidências do Banco Central e do Banco do Brasil. A tabela 4 mostra os resultados.

Os dados mostram a predominância quase absoluta do Sudeste na presidência do Banco Central: $88 \%$ dos seus titulares são oriundos da região. Entre os presidentes do Banco do Brasil, 82\% vinham das regiôes Sudeste e Sul, número bem acima de sua participação na populaçăo $(58,7 \%)$. Já as três regiōes pobres, que responderam em conjunto por $41 \%$ da populaçáo, ocuparam o cargo apenas $17 \%$ das vezes. Ao considerar a regiáo de nascimento dos 61 presidentes do Banco do Brasil, verificamos que apenas $17 \%$ eram oriundos do Nordeste, e os outros $83 \%$, das duas regióes ricas. Nenhum dos presidentes do banco nasceu no Norte ou no Centro-Oeste. Na avaliaçáo envolvendo apenas o período democrático, a interpretação não muda substancialmente.

Além da análise focada nas regiōes, fizemos também uma avaliaçáo de seus principais estados, individualmente. $\mathrm{O}$ gráfico 1 mostra a evolução, por período histórico, da ocupação de cargos por cada um deles.

Tabela 4

Ocupaçáo das Presidências do Banco Central e do Banco do Brasil pelas Regióes (\%)- 1889 a 2017

\begin{tabular}{lllllll}
\hline & Sudeste & Sul & Nordeste & Norte & Centro-Oeste & N \\
\hline Populaçáo & 43,8 & 14,9 & 30,3 & 6,0 & 4,9 & - \\
\hline Banco Central & 88,5 & 0 & 0 & 0 & 11,5 & 27 \\
\hline Banco do Brasil & 60,0 & 22,5 & 17,5 & 0,0 & 0,0 & 69 \\
\hline
\end{tabular}

Fontes: Abreu et al. (2001); sítios do Banco do Brasil e do Banco Central na internet; IBGE.

\section{Gráfico 1}

\section{Cargos no Poder Executivo, por região e período histórico}

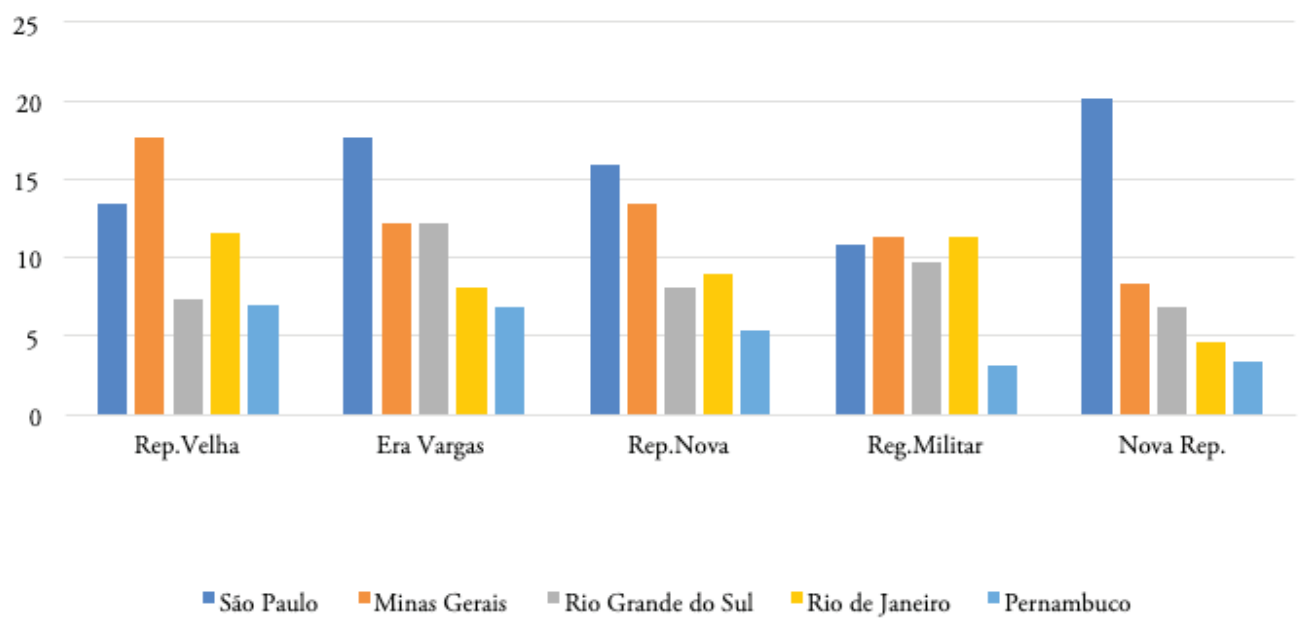

Fontes: Abreu et al. (2001); IBGE; sítios do Banco Central e do Banco do Brasil na internet; wikipedia. 
O gráfico mostra a prevalência de São Paulo na maior parte do período. Na Nova República, aumenta substancialmente a participação do estado na ocupação dos cargos mais importantes do país. É curioso que, mesmo estando no lado oposto no movimento revolucionário de 1930, coube a São Paulo uma participação importante durante os quinze anos de governo Vargas.

Minas Gerais saiu do primeiro lugar, na República Velha, para o segundo, nos períodos posteriores. Ao contrário de São Paulo, o estado reduziu sua participação nos últimos anos. O Rio Grande do Sul ocupou uma posição secundária ao longo do período republicano, mas cresceu em participação nos períodos militares: nos quinze anos de mandato de Getúlio Vargas, o gaúcho que liderou o golpe de estado de 1930; e durante o governo militar, confirmando sua forte tradição nessa área. O Rio de Janeiro revezou com o Rio Grande do Sul na terceira e na quarta posiçóes. A exemplo desse último, também teve uma participação importante no governo militar. Cabe registrar que a ascensão dos dois estados correspondeu a uma queda de São Paulo, o que acabou estabelecendo um razoável equilíbrio entre os quatro estados principais. Pernambuco, o estado líder do Nordeste, teve uma participação gradualmente menor, como aconteceu com toda a região. Na tabela 5 , apresentamos a ocupação de cargos pelos seis estados principais, ao longo de todo o período republicano.

Em uma leitura vertical da tabela, em que analisamos os estados individualmente, São Paulo merece destaque. $\mathrm{O}$ estado respondeu por cerca de $20 \%$ da população total do país em todo o período. No entanto, foi sub-representado na Câmara $(12,7 \%)$ e no Senado (4,4\%). É bastante curioso que, a despeito disso, o estado ocupou quase a metade das presidências da câmara baixa (46,4\%). Portanto, embora pareça ter sido prejudicado em uma instância na qual supostamente não deveria existir desproporcionalidade, tampouco deixou de exercer grande poder nela.

No Senado, a situação foi bem diferente: o estado ocupou a presidência apenas 6\% das vezes. Cabe acrescentar que o presidente da Câmara dos Deputados conta, comparativamente, com mais poderes internos do que o presidente do Senado. Isso porque há, na primeira, maior diferenciação e hierarquia entre os deputados, o que confere ao presidente mais destaque perante os seus pares. Já o Senado é uma casa mais colegiada, com maior igualdade entre os membros; praticamente não existe lá um "baixo clero". Com exceção dos suplentes, muitos senadores possuem longa experiência, tendo passado pelos cargos de deputado federal, prefeito de capital e governador.

A tabela mostra que São Paulo foi responsável por exatamente um terço dos presidentes brasileiros que governaram em período democráticos. Juntamente com a forte presença na presidência da Câmara dos Deputados, isso dá ao estado um grande poder de agenda sobre as questóes que vão ser discutidas na Casa. A tabela mostra também que a vice-presidência não parece ter sido uma ambição do estado. Quando se considera o período todo, apenas 3,7\% dos vice-presidentes fizeram carreira política por lá.

Apesar de o estado ter tido uma participação apenas condizente com seu tamanho no gabinete de ministros, percebemos que a coisa muda quando consideramos os ministérios principais. Em período democrático, aproximadamente $30 \%$ dos ministros da Fazenda eram provenientes de São Paulo. ${ }^{5}$ No caso do Ministério do Planejamento, o número sobe para $43 \%$. Vale citar também a importante presença paulista na direção do Banco Central (27\%), órgão fundamental na condução da política econômica do país. Esses achados convergem com os de Palotti e Cavalcante (2018), que identificaram uma propensão maior de representantes de São Paulo a ocupar cargos nos ministérios centrais ${ }^{6}$ no período de 1990 a 2016. Em contraste, percebemos que o estado não teve participação expressiva entre a elite militar: pouco mais de $3 \%$ dos ministros nessa área eram provenientes dele.

Esse predomínio paulista não foi sempre do mesmo tamanho. Na República Velha, a importância política do estado, apesar de grande, não estava à altura do seu crescente peso econômico e demográfico. Conforme afirma Schwartzman (1982), o Partido Republicano Paulista apoiou todos os candidatos presidenciais vitoriosos desde 1898, mas somente Campos Sales, Rodrigues Alves e Washington Luís eram paulistas. A relativa ausência da presidência correspondeu a uma participação reduzida nos ministérios. 
Tabela 5

Distribuiçáo dos Cargos pelos Principais Estados - 1889 a 2017

\begin{tabular}{|c|c|c|c|c|c|c|c|}
\hline & Período & SP & MG & $\mathbf{R J}$ & $\mathbf{R S}$ & PE & BA \\
\hline População & Todo & 20,0 & 12,4 & 7,2 & 6,5 & 5,3 & 8,3 \\
\hline Número de deputados & Todo & 12,7 & 12,6 & 7,9 & 7,0 & 6,0 & 8,4 \\
\hline Número de senadores & Todo & 4,4 & 4,4 & 4,4 & 4,4 & 4,4 & 4,4 \\
\hline \multirow{2}{*}{ Presidente da Câmara } & Todo & 31,0 & 25,9 & 5,2 & 8,6 & 8,6 & 5,2 \\
\hline & Democrático & 46,4 & 7,1 & 7,1 & 14,3 & 7,1 & 3,6 \\
\hline \multirow[t]{2}{*}{ Presidente do Senado } & Todo & 6,0 & 14,0 & 8,0 & 2,0 & 10,0 & 8,0 \\
\hline & Democrático & 8,0 & 0,0 & 4,0 & 4,0 & 4,0 & 4,0 \\
\hline \multirow[t]{2}{*}{ Presidente da República } & Todo & 29,0 & 18,4 & 21,1 & 18,4 & 0,0 & 0,0 \\
\hline & Democrático & 33,3 & 16,7 & 5,6 & 22,2 & 0,0 & 0,0 \\
\hline \multirow[t]{2}{*}{ Vice-Presidente da República } & Todo & 3,7 & 44,4 & 3,7 & 3,7 & 11,1 & 7,4 \\
\hline & Democrático & 12,5 & 25,0 & 0,0 & 12,5 & 12,5 & 0,0 \\
\hline \multirow[t]{2}{*}{ Ministros } & Todo & 16,0 & 11,0 & 4,9 & 8,0 & 4,6 & 5,6 \\
\hline & Democrático & 18,3 & 10,6 & 5,2 & 7,1 & 4,5 & 5,8 \\
\hline \multirow[t]{2}{*}{ Ministro da Fazenda } & Todo & 23,9 & 16,9 & 1,4 & 9,9 & 4,2 & 4,2 \\
\hline & Democrático & 29,7 & 13,5 & 0,0 & 8,1 & 2,7 & 5,4 \\
\hline \multirow[t]{2}{*}{ Ministro do Planejamento } & Todo & 43,8 & 31,3 & 6,3 & 0,0 & 0,0 & 0,0 \\
\hline & Democrático & 42,9 & 35,7 & 0,0 & 0,0 & 0,0 & 0,0 \\
\hline \multirow[t]{2}{*}{ Ministros Militares } & Todo & 3,2 & 4,5 & 44,6 & 20,4 & 3,2 & 5,8 \\
\hline & Democrático & 4,3 & 5,7 & 50,0 & 18,6 & 2,9 & 2,9 \\
\hline \multirow[t]{2}{*}{ Banco Central } & Todo & 26,9 & 3,9 & 50,0 & 0,0 & 0,0 & 0,0 \\
\hline & Democrático & 27,8 & 0,0 & 55,6 & 0,0 & 0,0 & 0,0 \\
\hline \multirow[t]{2}{*}{ Banco do Brasil } & Todo & 18,0 & 11,5 & 3,3 & 8,2 & 1,6 & 8,2 \\
\hline & Democrático & 20,7 & 6,9 & 0,0 & 3,5 & 0,0 & 6,9 \\
\hline
\end{tabular}

Fontes: Abreu et al. (2001); sítios do Senado e da Câmara dos Deputados na internet; IBGE; base de dados de Jairo Nicolau (1997); sítios do Banco Central e do Banco do Brasil na internet; wikipedia.

Minas Gerais foi o estado com a segunda maior população, se considerarmos todo o período republicano (12,4\%). Embora tenha sido sub-representado na Câmara dos Deputados nos primeiros anos da República, aproximou-se da proporcionalidade nas últimas décadas: quando se considera o período todo, seu número de representantes acaba equivalendo ao tamanho da população. No entanto, salta aos olhos a sua participação na presidência da Casa, que foi mais de duas vezes maior (26\%) do que a sua proporção na população ou no que diz respeito ao número de cadeiras ocupadas. É curioso que esse nú- mero cai bastante em períodos democráticos (7\%).

Merece destaque também a grande participação do estado na presidência da República (18,4\%), enquanto sua proporção na população era de $12,4 \%$. Minas Gerais e São Paulo foram responsáveis por praticamente metade dos presidentes que o Brasil já teve. É ainda mais expressiva a participação de Minas na vice-presidência da República: 44\% do tempo. Mesmo que caia para 25\% quando se conta apenas o período democrático, o estado fica ainda bem acima de sua participação na população. É grande também a quantidade de ministros da Fazenda e do Planeja- 
mento que fizeram carreira política em suas terras, $17 \%$ e $31 \%$, respectivamente.

Quatro cargos marcaram a participação, no poder central, do Rio de Janeiro, que respondia por $7,2 \%$ da população do país. $\mathrm{O}$ primeiro é o de presidente da República, dos quais fez 21\%. O segundo é de ministro militar, reforçando a vocação do estado nessa área: aproximadamente metade veio de lá. O terceiro cargo que se destaca entre os fluminenses é de presidente do Banco Central: aqui também nada menos que metade deles nasceu no estado. A exemplo do que acontece às regióes, esses números sugerem que os titulares de alguns órgãos são mais frequentemente escolhidos em alguns estados, embora isso não seja regra.

O Rio Grande do Sul teve uma participação bastante expressiva em alguns cargos. A despeito de ter abrigado apenas $6,5 \%$ da população do país, o estado foi responsável por $14,3 \%$ dos presidentes da Câmara dos Deputados em períodos democráticos. Participou também com um número expressivo de presidentes da República: $18 \%$, quando se considera o período todo; $22 \%$ quando se computa apenas o período democrático. Como o Rio de Janeiro, o Rio Grande do Sul tem forte vocação militar, e não foi à toa que aproximadamente $20 \%$ dos ministros da área tinham relação com o estado. Pernambuco e Bahia são os estados mais importantes do Nordeste. A exemplo de toda a região, não exerceram papel de destaque na política nacional durante o período republicano.

Aproveitamos a oportunidade para testar a hipótese de que os ministérios "de gastos", ou de "clientela", são ocupados por critérios regionais (Abranches 1988, Abrucio 1998). Com dados referentes ao período de 1946 a 1964, os autores encontraram ministérios reservados para alguns estados: Saúde e Educação, por exemplo, seriam cativos da Bahia; e Viação e Obras, do Rio de Janeiro. Quando olhamos para um período mais amplo, porém, tais percepçóes não se sustentam. De acordo com nossos dados, o Ministério da Educação ficou dividido principalmente entre São Paulo (18,8\%), Bahia (18,8\%) e Minas Gerais (16,7\%). O Ministério da Saúde teve como ocupantes sobretudo políticos do Rio de Janeiro (17,5\%) e de São Paulo (20\%). A pasta de Viação e Obras foi distri- buída entre vários estados; a maior participação foi a de São Paulo, com apenas 14,5\%. Difícil falar em critério regional, aqui.

\section{Consideraçóes finais}

Esse estudo aborda a desproporcionalidade de representação no país em uma perspectiva ampla, que considera não apenas o que acontece no Legislativo, mas também em diversos órgãos do Poder Executivo. À primeira vista, pode parecer que o preceito de igualdade de representaçáo entre os estados na câmara alta, que copiamos da Constituição norte-americana, tem o objetivo de evitar a tirania da maioria. Aqui, como nos Estados Unidos, essa teria sido uma forma de evitar que os estados menores fossem esmagados pelos maiores. No Brasil, esse propósito seria reforçado com a desproporcionalidade presente também na câmara baixa. ${ }^{7}$ Porém, quando olhamos para os principais cargos da República, muitos deles até mais importantes do que os próprios cargos de deputado ou de senador, percebemos que, nesses quase 130 anos de República, os estados grandes (e ricos) nunca perderam a hegemonia.

Em termos regionais, a região Sudeste como um todo merece destaque. Percebemos que ela predominou na ocupação da presidência da República e de outros órgãos cruciais, relacionadas à política macroeconômica. No caso de São Paulo, o estado mais relevante e também o mais sub-representado no Legislativo, a supremacia aparece claramente. A despeito de abrigar apenas $20 \%$ da população do país, o estado ocupou quase metade das presidências da Câmara; um terço das presidências da República; 30\% e 43\% dos poderosos Ministérios da Fazenda e do Planejamento, respectivamente; e $28 \%$ das presidências do Banco Central. Esteve bastante presente, portanto, nos cargos mais importantes, que controlam a agenda política e econômica do país. Obviamente, esses números não explicam tudo; mas tampouco parecem aleatórios.

A pergunta que fica: por que é assim? Qual negociação foi feita na distribuição do poder entre as regiōes no Brasil? Como ela pode ser mantida? Como um estudo embrionário, não temos respostas 
definitivas. No máximo, conseguimos apresentar algumas hipóteses plausíveis. Sobre a desproporcionalidade de representação no Brasil, faz sentido a ideia de pacto entre elites sugerida pela literatura antiga e apresentada na introdução a esse texto. Acrescentamos algo de novo a essa discussão, porém. Nossa sugestão é que esse pacto envolve também os cargos do Poder Executivo, que tem igualmente muita força. É por meio deles que as elites dos estados fortes mantêm o controle sobre as questôes de âmbito nacional e grande relevância. Além da preponderância nas presidências da República e da Câmara dos Deputados, merece destaque a ocupaçáo, pelos estados ricos, de órgãos e instâncias responsáveis pela política macroeconômica: os ministérios da Fazenda e do Planejamento e as presidências do Banco Central e do Banco do Brasil. Dessa forma, a predominância dos estados maiores em cargos-chave do Poder Executivo, e também na presidência da Câmara dos Deputados, apresenta-se como um mecanismo a mais para garantir alguma coesão, homogeneidade e eficácia ao sistema, proporcionando, assim, maior capacitação do poder central (demos enabling). Em outras palavras, a despeito da sobre-representação dos estados menores nas duas casas legislativas, sua desvantagem (ou sub-representação) nos cargos principais do Poder Executivo reduz seu possível poder de obstrução.

Outro ponto a considerar é que, enquanto os parlamentares são eleitos por distritos geograficamente concentrados, o presidente é eleito por toda a nação, com uma contribuição maior dos estados mais populosos. Isso, por si só, já dá a eles uma vantagem comparativa, na disputa com outros estados. Essa vantagem cresce quando esses estados são também os mais dotados de recursos naturais, financeiros, tecnológicos, industriais, acadêmicos e humanos. Em uma sociedade tão heterogênea e desigual como a brasileira, e com um sistema político tão fragmentado e difuso, torna-se necessária uma força predominante, capaz de implantar, coordenar e promover a unidade das políticas nacionais. Essa força parece vir sobretudo dos estados mais fortes. Isso não significa que os estados menores (e mais pobres) nâo deem a sua contribuição ou que ela seja menos qualificada.

Nossos achados sugerem pistas para compreender por que os estados e regióes mais populosos (e, coincidentemente, ricos) permitiram que estados e regióes menores (e, coincidentemente, pobres) predominassem no Legislativo, especialmente no Senado. Aparentemente, os primeiros não foram prejudicados no exercício do poder efetivo. As evidências que encontramos reforçam a ideia de que o federalismo brasileiro é hierárquico: apesar do texto constitucional afirmar que os estados são iguais, sabemos que, na prática, as coisas não são exatamente assim. Embora o Sul e o Sudeste tenham sofrido um déficit de representação no Legislativo, as duas regióes foram mais que compensadas com cargos no Executivo.

Trata-se, aqui, de um estudo inicial, parte de um projeto maior que pretende analisar o impacto da desproporcionalidade na configuração e no funcionamento do sistema político brasileiro como um todo. Adotamos uma abordagem macro e de longo prazo, abrangendo toda a história republicana, que sabemos não ser homogênea, apresentando diferentes graus de desproporcionalidade e de centralização. Isso nos impediu de considerar outros fatores importantes na escolha dos auxiliares do presidente. Novas contribuições serão muito bem-vindas; elas poderão dedicar-se a períodos mais curtos e controlar outras variáveis relevantes, tais como a vinculação partidária das autoridades, a participação dos partidos na coalizão, a distância ideológica em relação ao presidente, o grau de coalescência (partidária e estadual), a qualidade da democracia, a natureza e importância individual dos ministérios, as características pessoais dos ocupantes dos cargos, sua qualificação técnica e trajetória profissional, seu vínculo com segmentos econômicos e/ ou grupos corporativos, a proximidade pessoal com o presidente, o índice de aprovação desse último e o tempo restante de mandato, entre outros.

O estudo das relações de poder no Brasil ficou muito concentrado no Legislativo, nos partidos e nas questôes eleitorais. Estes são, de fato, fundamentais. $\mathrm{O}$ poder, porém, não está apenas nas instituições formais. Ele é multidimensional, envolvendo também aspectos simbólicos, demográficos, regionais, sociais, econômicos e financeiros que merecem ser considerados. 


\section{Notas}

1 O cargo de presidente do Banco do Brasil foi incluído em funçáo da importância da instituição na história do país. Criado em 1808 por D. João VI, quando a família real portuguesa migrou para o Brasil, fugindo das tropas napoleônicas,foi o principal instrumento de crédito do governo federal durante toda a República, desempenhando também as funçóes de autoridade monetária até a criação do Banco Central, em 1964.

2 Apenas um dos 26 presidentes do BC passaria por nosso critério de escolha por motivaçáo política, apesar do perfil bastante tecnocrático: Fernando Milliet, que também foi presidente do Banespa e secretário de Administração do governo de Sáo Paulo.

3 Dos cinco presidentes da Câmara oriundos de regióes mais pobres do país, um não terminou o mandato: o deputado Severino Cavalcante, parlamentar pouco expressivo, escolha em função de uma divisão na base de apoio ao governo, e não por méritos próprios.

4 Como os militares náo se envolvem explicitamente em assuntos políticos e costumam passar por diversos estados durante a carreira, usamos como referência, no caso destes, o estado natal.

5 Abranches (1988) identificou números ainda mais altos: entre 1946 e 1964, 41\% dos ministros da Fazenda eram provenientes de São Paulo.

6 De forma semelhante a Batista (2017), os dois autores identificaram como ministérios centrais os seguintes: Finanças, Planejamento, Justiça, Saúde, Educação e Defesa.

7 Um estudo minucioso sobre a desproporcionalidade na Câmara dos Deputados foi realizado por Nicolau (1997).

\section{BIBLIOGRAFIA}

ABRANCHES, S. (1988), "Presidencialismo de coalizão: o dilema institucional brasileiro", in Dados, 31(1): pp.5-38.

ABREU, A.; Beloch, I.; Lattman-Weltman, F.; Lamarão, S. (2001), Dicionário histórico-biográfico brasileiro, Rio de Janeiro: CPDOC/FGV.

ABRUCIO, F. (1998), Os baróes da federação: os governadores e a redemocratizaçâo brasileira, São Paulo: Hucitec.

ALBALA, A. (2017), "Bicameralism and coalition cabinets in presidential polities: A configurational analysis of the coalition formation and duration processes", in The British Journal of Politics and International Relations, 19(4): pp.735-754.

AMES, B. (1986), "O Congresso e a política orçamentária no Brasil durante o período pluripartidário", in Dados, 29(2): pp.177-205.

AMES, B. (2003), Os Entraves da Democracia no Brasil, Rio de Janeiro: Editora FGV.

AMORIM NETO, O. (2000), "Gabinetes presidenciais, ciclos eleitorais e disciplina legislativa no Brasil”, in Dados, 43(3): pp.479-519.

AMORIM NETO, O. (2006), "The presidential calculus: Executive policy making and cabinet formation in the Americas", in Comparative Political Studies, 39(4): pp.415-440.

AMORIM NETO, O. (2007), "O Poder Executivo, centro de gravidade do sistema político brasileiro", in L. Avelar e A. O. Cintra, Sistema político brasileiro: uma introdução, São Paulo/ Rio de Janeiro, Konrad Adenauer/Editora da Unesp, pp.123-132.

AMORIM NETO, O. e F. Santos (2013), "O Rio de Janeiro e o Estado Nacional (1946-2010)”, in Dados, 56(3): pp.467-496.

ARRETCHE, M. e J. Rodden (2004), “Política distributiva na federação: estratégias eleitorais, barganhas legislativas e coalizões de governo", in Dados, 47(3): pp.549-576.

BATISTA, M. (2017), “Taking Portfolios Difference Seriously: A Composite Measure Based on Policy, Office, and Budget in Brazil”, in Brazilian Political Science Review, (11) 1: pp.1-28.

BRITTO, L. N. (1965), "A representação proporcional", in Revista de Informação Legislativa, 2(6): pp.17-30.

CAMPELLO DE SOUZA, M.C. (2006), "Federalismo no Brasil: aspectos político-institucionais (1930-1964)", in Revista Brasileira de Ciências Sociais, 21(61): pp.7-40.

CAREY, J. M. \& Reinhardt, G. Y. (2004), "State level institutional effects on legislative coalition unity in Brazil", in Legislative Studies Quarterly, 29(1): pp.23-47.

FIGUEIREDO, A. e F. Limongi (1999), Executivo e Legislativo na nova ordem constititucional, Rio de Janeiro, Editora FGV. 
GIBSON, E., Calvo, E. e Falleti, T. (2003), "Federalismo realocativo: sobre-representação legislativa e gastos públicos no hemisfério ocidental", in Opinião Pública, 9(1): pp.98-123.

GIBSON, E., Calvo, E. e Falleti, T. (2004), "Reallocative federalism: Legislative overrepresentation and public spending in the western hemisphere", in Federalism and Democracy in Latin America, Baltimore: The John Hopkins University Press, pp.173-196.

HIROI, T. \& Renno, L. (2014), "Dimensions of legislative conflict: coalitions, obstructionism, and lawmaking in multiparty presidential regimes", in Legislative Studies Quarterly, 39(3): pp.357-386.

KINZO, M. D. (1990), "São Paulo e o Brasil: uma desigualdade política”, São Paulo em perspectiva, 4(1): pp.37-41.

LEVINE, R. (1980), A velha usina: Pernambuco na federação brasileira, 1889-1937, Rio de Janeiro: Paz e Terra.

LIJPHART, A. (1999), Patterns of Democracy: Government Forms and Performance in Thirty-Six Countries, New Haven: Yale University Press.

LLANOS, M. \& Nolte, D. (2003), "Bicameralism in the Americas: around the extremes of symmetry and incongruence", in The Journal of Legislative Studies, 9(3): pp.54-86.

LOVE, J. (1980), São Paulo in the Brazilian federation, 1889-1937, Stanford: Whoopie Cushion Publishing.

LOVE, J. (1985), "O Rio Grande do Sul como fator de instabilidade na República Velha", in História geral da civilização brasileira, Difel: São Paulo, pp.99-122.

MARTÍNEZ-GALLARDO, C. (2012), "Out of the cabinet: what drives defections from the government in presidential systems?", in Comparative Political Studies, 45(1): pp.62-90.

MENEGUELLO, R. (1998), Partidos e governos no Brasil contemporâneo, Rio de Janeiro: Paz e Terra.

NEIVA, P. (2011), "Coesão e disciplina partidária no Senado Federal", in Dados, 54(2): pp.289-318.

NEIVA, P. (2006), "Os determinantes da existência e dos poderes das câmaras altas: Federalismo ou presidencialismo?, in Dados, 59(2): pp.269-299.
NEIVA, P. e soares, M. (2013), "Senado brasileiro: casa federativa ou partidária?", in Revista Brasileira de Ciências Sociais, 28(81): pp.97-115.

NICOLAU, J. (1997), "As distorçôes na representação dos estados na Câmara dos Deputados brasileira", in Dados, 40(3): pp.527-545.

PALERMO, V. (2000), "Como se governa o Brasil? O debate sobre instituiçôes políticas e gestão de governo", in Dados, 43(3): pp.521-557.

PALOTTI, P. L. e P. L. C., Cavalcante (2018), "Does one size fit all? An analysis of portfolio allocation in the Brazilian multiparty presidential system", in Opinião Pública, 24(2): pp.427-455

PEREIRA, C. e MUELLER, B. (2002), “Comportamento estratégico em presidencialismo de coalizão: as relações entre Executivo e Legislativo na elaboraçáo do orçamento brasileiro", in Dados, 45(2): pp.265-301.

REYNOSO, D. (2001), "Distritos y escaños en Brasil: antecedentes, diagnóstico y consecuencias partidarias del malaporcionamiento", in Política y Gobierno, (VIII)1: pp.167-191.

SAMUELS, D. (2002), "Progressive ambition, federalism, and pork-barreling in Brazil", in Legislative Politics in Latin America, Nova York, Cambridge University Press.

SAMUELS, D. (2003), Ambition, federalism, and legislative politics in Brazil, Cambridge: Cambridge University Press.

SAMUELS, D. \& Mainwaring, S. (2004), "Strong federalism, constraints on the central government, and economic reform in Brazil", in E. Gibson (org.), Federalism and Democracy in Latin America, Baltimore: The John Hopkins University Press, pp. 85-130.

SAMUELS, D. \& SnydeR, R. (2001), "The value of a vote: malapportionment in comparative perspective", in British Journal of Political Science, 31(04): pp.651-671.

SANTOS, W. G. (1997), "Representação, proporcionalidades e democracia", in Estudos Eleitorais, 1(1), Tribunal Superior Eleitoral.

SCHWARTZMAN, S. (1975), São Paulo e o Estado nacional, São Paulo: Difel.

SCHWARTZMAN, S. (1982), Bases do autoritarismo brasileiro, Rio de Janeiro: Campus. 
SNYDER, R., \& Samuels, D. (2004), "Legislative Malapportionment in Latin America", in Gibson, E. (org.), Federalism and Democracy in Latin America, pp.131-172.

SOARES, G. A. D. (1973), "Desigualdades eleitorais no Brasil", in Revista de Ciência Politica, 7 , pp.22-48.

SOARES, M. M. e Lourenço, L. (2004), "A representação política dos estados na federação brasileira", in Revista Brasileira de Ciências Sociais, 19(56): pp.113-154.

SOARES, M. M. e NEIVA, P. (2011), "Federalism and public resources in Brazil: federal discretionary transfers to states", in Brazilian Political Science Review, 5(2): pp.94-116.

SOUZA, C. (1998), "Intermediação de interesses regionais no Brasil: o impacto do federalismo e da descentralização", in Dados, 41(3): pp.569-594.

STEPAN, A. (1999), "Para uma nova análise comparativa do federalismo e da democracia: federaçóes que restringem ou ampliam o poder do demos", in Dados, 42(2): pp.197-251.

STEPAN, A. (2004), "Toward a new comparative politics of federalism, multinationalism, and democracy: beyond Rikerian federalism", in E. Gibson (org.), Federalism and Democracy in Latin America, Baltimore: John Hopkins University Press, pp.29-84.

TAVARES, J. A. G. (1995), "Desigualdades regionais, desigualdades políticas e reforma eleitoral no Brasil", in Indicadores Econômicos FEE, 23(3), pp.191-217.

TOMMASI, M. (2002), "Federalism in Argentina and the reforms of the 1990s", in Working Paper 147, Center for Research on Economic Development and Policy Reform, Stanford University.

TSEBELIS, G. (1995), "Decision making in political systems: Veto players in presidentialism, parliamentarism, multicameralism and multipartyism”, in British Journal of Political Science, 25(3): pp.289-325.

TURGEON, M. e P. Cavalcante (2014), “Desproporcionalidade da representação dos estados no Congresso Nacional e seus efeitos na alocação dos recursos federais", in Textos para Discussão,
1(1980), Brasília: Instituto de Pesquisa Econômica Aplicada.

WIRTH, J. D. (1982), O fiel da balança: Minas Gerais na Federação Brasileira, 1889-1937, Rio de Janeiro: Paz e Terra. 


\section{Apêndice 1}

\section{Gráfico 1}

\section{Proporção da População, por Regiáo e Período Histórico}

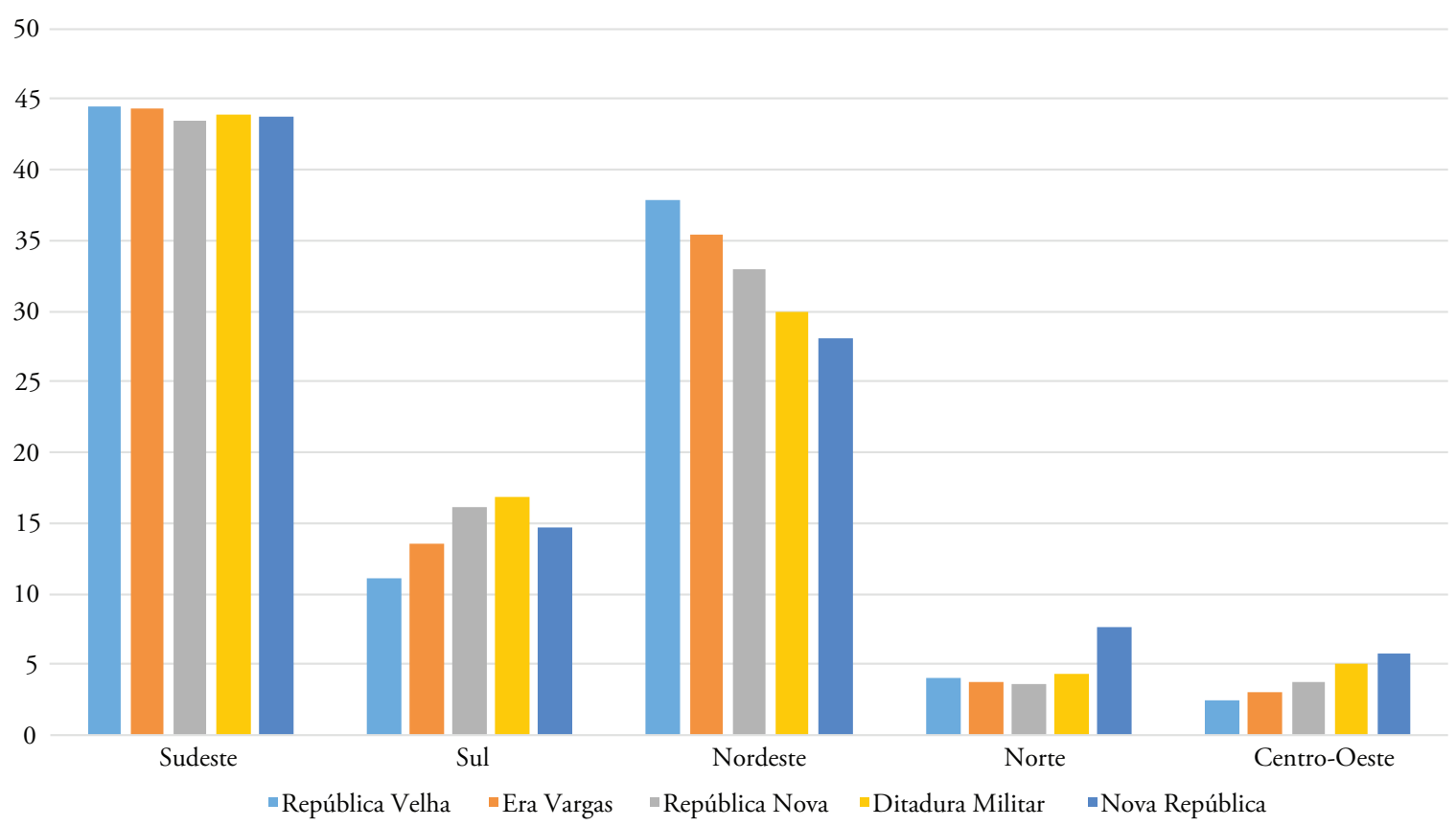

Fontes: Abreu et al. (2001); IBGE; sítios do Banco Central e do Banco do Brasil na internet; wikipedia. 


\section{Gráfico 2}

\section{Proporçáo de Parlamentares, por Regiáo e Período Histórico}

45

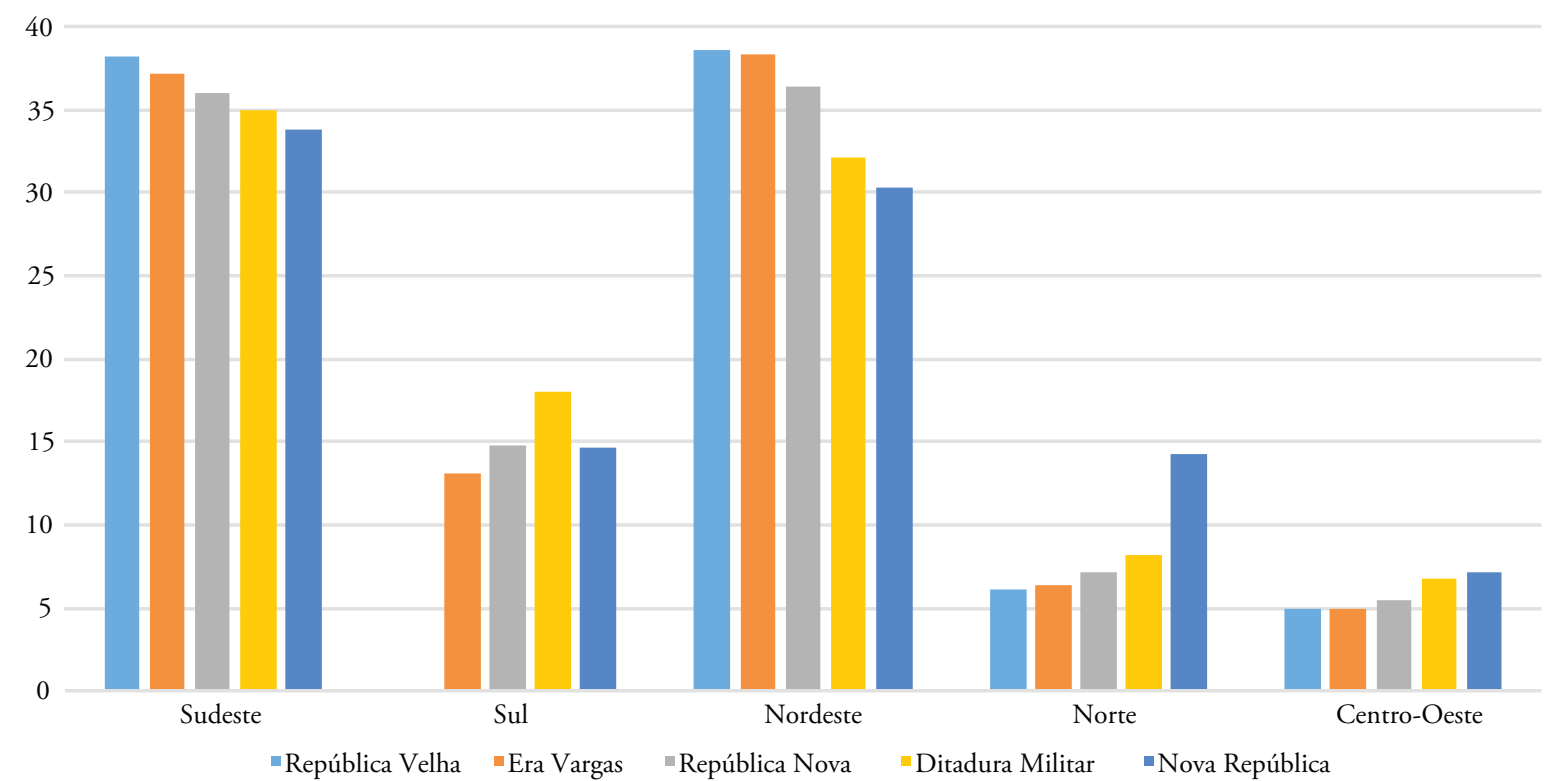

Fontes: Abreu et al. (2001); IBGE; sítios do Banco Central e do Banco do Brasil na internet; wikipedia.

Gráfico 3

Proporção de Parlamentares, por Regiáo e Período Histórico

60

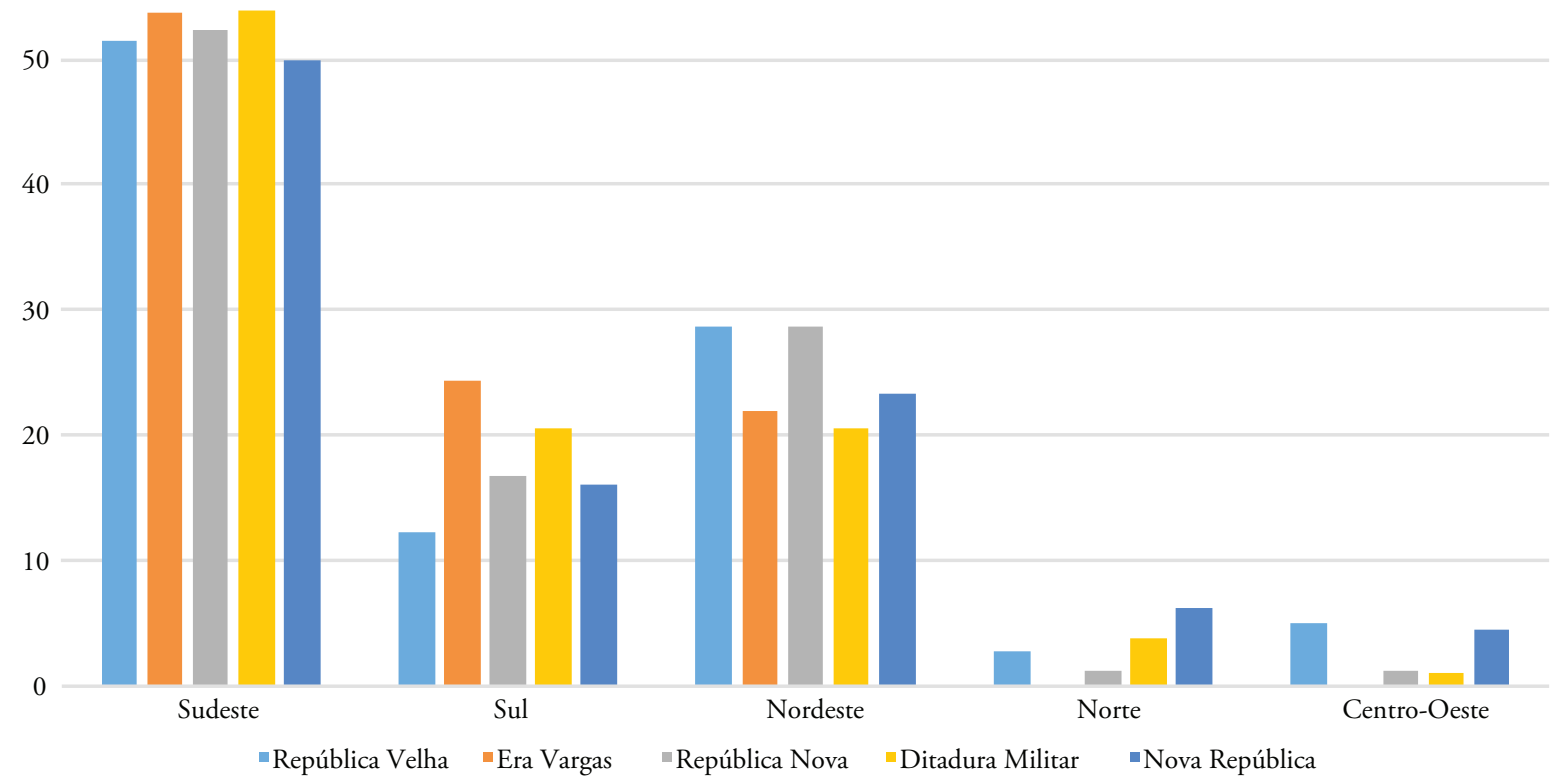

Fontes: Abreu et al. (2001); IBGE; sítios do Banco Central e do Banco do Brasil na internet; wikipedia. 


\section{TODOS OS ESTADOS SÃO IGUAIS, MAS ALGUNS SÃO MAIS IGUAIS QUE OS OUTROS}

\section{Pedro Neiva e Taeko Hiroi}

Palavras-chave: Desproporcionalidade de representação; Federalismo; Executivo; Legislativo; Ministério.

Nesse estudo, procuramos identificar o peso dos estados na ocupação dos cargos mais importantes do país durante todo o período republicano. $\mathrm{O}$ nosso ponto principal é que os estados mais ricos, especialmente São Paulo, apesar de terem sido sub-representados no Senado Federal e na Câmara dos Deputados, predominaram na ocupaçáo de outros cargos ainda mais importantes, tais como os de presidente da República, ministros da área econômica, presidentes do Banco Central e presidentes da Câmara dos Deputados. Dessa forma, pretendemos contribuir para uma melhor compreensão do arranjo federativo brasileiro, que tem sido analisado principalmente com a perspectiva da autonomia ou da dependência das subunidades territoriais em relação à União; pouco tem sido feito no sentido de compreender a contribuição de tais subunidades para a estruturação do poder central.

\section{ALL STATES ARE EQUAL, BUT SOME ARE MORE EQUAL THAN OTHERS}

\author{
Pedro Neiva and Taeko Hiroi
}

Keywords: Disproportionality of representation; Federalism; Executive; Legislative; Ministry.

This paper aims to identify the weight of the individual states in occupying the most critical positions in the country throughout the republican period. Our main argument is that the wealthier states, especially São Paulo, despite being underrepresented in the Federal Senate and the Chamber of Deputies, prevailed in the occupation of other more critical positions, such as those of President of the Republic, ministers of economic affairs, presidents of the Central Bank and presidents of the Chamber of Deputies. Hence, we contribute to a better understanding of the Brazilian federative arrangement, which has been analyzed mainly with the perspective of autonomy or of the dependence of territorial subunits in relation to the Union. Little has been done to understand the contribution of such subunits to the structuring of central power.

\section{TOUS LES ÉTATS SONT ÉGAUX, MAIS CERTAINS SONT PLUS ÉGAUX QUE D'AUTRES}

\author{
Pedro Neiva et Taeko Hiroi
}

Mots-clés: Représentation en disproportion; Fédéralisme; Exécutif; Législatif; Ministère.

Notre but, dans cette étude, a été celui d'identifier le poids des États membres dans l'occupation des postes les plus importants au Brésil tout au long de la période républicaine. Notre principal argument est que les États membres les plus riches, en particulier São Paulo, bien qu’ils aient été sous-représentés au Sénat fédéral et à la Chambre des Députés, ont prédominé dans l'occupation d'autres postes encore plus importants, tels que ceux de président de la République, ministres du secteur économique, présidents de la Banque Centrale et présidents de la Chambre des Députés. Ainsi, nous avons l'intention de contribuer à une meilleure compréhension de l'arrangement fédératif brésilien, qui a été analysé principalement dans la perspective de l'autonomie ou de la dépendance vis-à-vis des sous-unités territoriales par rapport à l'Union ; peu a été fait pour comprendre la contribution de ces sous-unités à la structuration du pouvoir central. 